\title{
REFLECTANCE SPECTROMETRY OF ROCKS FROM THE COMSTOCK LODE (VIRGINIA CITY, NEVADA, USA) AND ITS COMPARISON WITH X- RAY DIFFRACTION
}

\author{
T.I.Ribeiro de Almeida ${ }^{1}$ \& A.P.Crósta ${ }^{2}$
}

KEY-WORDS: Reflectance spectrometry, hydrothermal alteration, Virginia City.

RIBEIRO DE ALMEIDA, T.I.; CRÓSTA, A.P. (1997) Reflectance spectrometry of rocks from the Comstock Lode (Virginia City, Nevada, USA) and its comparison with X-ray diffraction. Bol.IGUSP, Sér.Cient., 28:85-100.

\begin{abstract}
This paper presents the results of mineralogical analysis of hydrothermal altered rocks from the Comstock Lode, near Virginia City, Nevada, USA, using two different techniques: reflectance spectrometry and X-ray diffraction. These results are discussed based on their quickness, accuracy and low costs. The applicability to mineral mapping using high spectral resolution remote sensing images is also briefly discussed. Comparison of the results obtained for both techniques have a good degree of correlation, showing that reflectance spectrometry represents an expedite, simple and relatively inexpensive technique, capable of mapping numerous minerals in the field or in laboratory.
\end{abstract}

\section{RESUMO}

Este trabalho apresenta resultados de análises mineralógicas de rochas com alteração hidrotermal do Lode de Comstock, próximo a Virginia City, Estado de Nevada, EUA, utilizando duas diferentes técnicas: espectrometria de reflexão e difração de raio-X. Os resultados são discutidos em função de sua rapidez e facilidade de obtenção e acuracidade. Discute-se ainda, brevemente, sua aplicabilidade ao mapeamento mineral utilizando imagens de sensoriamento remoto com alta resolução espectral. A titulo de ilustraçăo, apresenta-se uma imagem TM-Landsat da região de estudo, na qual pode-se observar a caracteristica resposta das áreas alteradas hidrotermalmente. A comparação dos resultados obtidos com as duas técnicas apresentou um razoável grau de correlação, mostrando que a espectrometria é uma ferramenta expedita, simples, relativamente barata e capaz de identificar no campo ou em laboratório minerais de interesse na prospecção de áreas com alteraçăo hidrotermal.

\section{INTRODUCTION}

Reflectance spectrometry (RSp) is an analytical technique that allows quick identification of minerals based on their spectral properties in the wavelength regions of the electromagnetic spectrum between 400 and 2,500 $\mathrm{nm}$ (Goetz, 1989). These correspond to the visible (VIS - 400 to $700 \mathrm{~nm}$ ), near-

\footnotetext{
'Departamento de Geologia Econòmica e Geofisica Aplicada, Instituto de Geociências/USP, Såo Paulo, Brasil. E-mail: tirdalme $a$ usp.br.

2Instituto de Geociências/UNICAMP, Săo Paulo, Brasil E-mail: alvaro@ige unicamp br
} 
infrared (NIR - 650 to $1,000 \mathrm{~nm}$ ) and mid or shortwave infrared (SWIR 1,000 to $2,500 \mathrm{~nm}$ ) regions. The way some minerals interact with energy from the Sun or from artificial sources are recorded by spectrometers and used to identify spectral features which are diagnostic of the respective minerals. This principle constitutes the basis of remote sensing, since sensors are a type of reflectance spectrometer which measures the above mentioned wavelength regions, usually at a limited spectral resolution, defined by the number and the wavelength range of their spectral bands.

Spectral features can be used to identify several minerals, but not all of them. Minerals formed by hydrothermal alteration processes, such as ferric oxides, hydroxides and sulphates (hematite, goethite, limonite and jarosite), "clay" minerals (a generic term that comprises several $\mathrm{O}$-H-bearing minerals, including kaolinite, montmorillonite, illite, chlorite, etc.) and carbonates (calcite and dolomite) are amongst those that produce spectral features. For this reason, remotely sensed images have been used to map hydrothermal alteration, thus representing an important information source in mineral exploration.

RSp has been used as a supporting analytical technique to remote sensing and image processing and interpretation (e.g. Hunt \& Ashley, 1979; Rowan, 1983; Lee \& Reines, 1984; Rockwell, 1991; Taranik et al., 1991) and, recently some brazilian studies (e.g. Crósta, 1996a; Crósta et al., 1996; Hernandes \& Crósta, 1996; Prado \& Crósta, 1997). Early spectrometers that could operate in all three spectral regions (VIS, NIR and SWIR), also known as full-range spectrometers, were basically laboratory instruments, of large dimensions and weight. It was not until recently that these instruments coupled with small (laptop or palmtop) computers became truly portable and could be taken into the field.

Full-range remote sensing has been an important research area, which has prompted the development of sensors with very high spectral resolution, similar to the resolution of reflectance spectrometers. Some sensors of this kind, known as imaging spectrometers, already exist, flying in airborne platforms (such as AVIRIS - Carrere, 1989). Orbital imaging spectrometers, such as Lewis/HSI and ARIES, are also under development, and should be launched in the near future (Taranik \& Crósta, 1994; Crósta, 1996b).

Besides being used as a support to remote sensing, RSp is rapidly becoming an exploration technique by itself. Recent advances in spectral technology have led to the development of portable reflectance spectrometers operating in the so-called full-range ( 400 to 2,500 $\mathrm{nm})$. These portable instruments provide results which are equivalent to those here presented for a laboratory spectrometer (e.g. the Beckman UV5240 ), with the advantages of doing the analysis in the field, directly from outcrops and providing the results in real time. This is further enhanced by the use of software coupled to these instruments, that can compare the spectra of samples being analyzed with reference standards from a spectral library (such as the USGS Digital Spectral Library) and identify the minerals on the spot.

These portable instruments are currently being used in the field by exploration companies to prepare detailed maps of alteration zones over targets that have been previously identified by satellite remote sensing. As currently operating multispectral sensors like Landsat Thematic Mapper have only the capability of locating alteration zones, without being able to determine its precise mineralogy, the combined use of both satellite or airborne remote sensing 
and portable spectrometers in the field is a powerful exploration tool. The use of these instruments in the field is likely to continue even after operational imaging spectrometers such as ARIES become available onboard satellites, since it will always provide a much higher degree of spatial detail, needed to confirm and help the image data interpretation.

This paper reports the results obtained from spectral analysis of hydrothermally altered rocks. The same samples were analyzed by X-ray diffraction, in order to evaluate to what extent an expedite and relatively inexpensive technique such as RSp can map mineralogy of interest for exploration research. RSp is an analytical uncommon tool in Brazil and the results are presented here to show some of its capabilities. For this reason a detailed methodological explanation about the technique was also included.

The study area is the Comstock Lode, near Virginia City, State of Nevada, USA. This is a well known mining district explored for silver and gold, first discovered around 1850 , resulting in the so-called Washoe Gold Rush (Hess, 1987). Numerous mines operated in the Comstock Lode during the last century but most of them were exhausted by the beginning of this century.

The area was selected for this study due to the widespread hydrothermal alteration that affected the volcanic rocks in the region. The samples used in this study were collected at the Comstock Fault Zone, along which the alteration is very intense and well depicted at the surface.

\section{LOCATION AND GEOLOGY OF THE STUDY AREA}

The study area is defined by the geographical coordinates $39^{\circ} 18 \mathrm{~N}$ and $119^{\circ} 39^{\prime} \mathrm{W}$, between the towns of Vir- ginia City and Gold Hill (Fig. 1). The access is easy at any time, by paved roads, and is crossed by Nevada State Highway 341 .
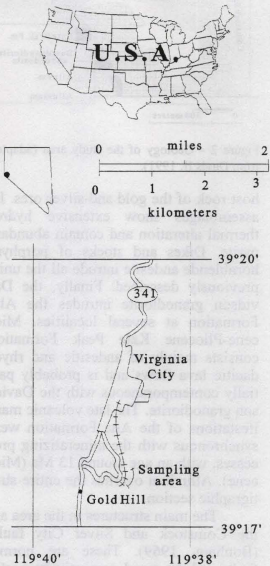

Figure 1 - Location of the study area (adapted from Hess et al., 1987).

The local geology of the study area is shown in Figure 2 (Hudson, 1986). According this author, siliceous tuffs unconformably overlie Mesozoic rocks and are unconformably overlain by the Alta Formation, below described. All these rocks and units are of Tertiary age. The Alta Formation is the main 


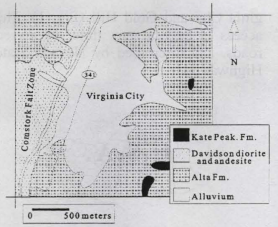

Figure 2 - Geology of the study area (adapted from Davis II. 1991).

host rock of the gold and silver ores. Its assemblages show extensive hydrothermal alteration and contain abundant pyrite. Dikes and stocks of porphyry hornblende andesite intrude all the units previously described. Finally, the Davidson granodiorite intrudes the Alta Formation at several localities. Miocene-Pliocene Kate Peak Formation consists mainly of andesitic and rhyodacitic lava flows and is probably partially contemporaneous with the Davidson granodiorite. The late volcanic manifestations of the Alta Formation were synchronous with the mineralizing processes, with an age around $13 \mathrm{Ma}$ (Miocene). Alluvium overlies the entire stratigraphic section.

The main structures in the area are the Comstock and Silver City faults (Bonham, 1969). These are normal faults, which trend respectively northeast and southeastward, dipping approximately $45^{\circ}$ to the east. Gold and silver concentrations are found within epithermal veins that dominantly occur in association with these fault zones. The Silver City fault joins the Comstock fault very near and south of Gold Hill. The third important fault is the Occidental, two miles east of Comstock, which shows lower a concentration of mineralized zones. A number of north- east and northwest-trending faults also occur in the Comstock district.

Samples for spectral analysis were collected at outcrops of the Alta Formation, defined by Gianella (1936, apud Bonham, 1969). According to the map published by Bonham (1969), the Alta Formation consists predominantly of pyroxene, hornblende-pyroxene, and hornblende andesite flows, flows breccias, tuff breccias and mud flow breccias. It also contains lesser amounts of intrusive andesite, soda trachyte, basalts and lenses of rhyolitic tuff and clastic sediments. Compositional variations in these rocks may be attributed to hydrothermal alteration, as indicated by the presence of high $\mathrm{H}_{2} \mathrm{O}$ and $\mathrm{CO}_{2}$ and the occurrence of $\mathrm{FeS}_{2}$, "beside" the observed pyrite.

Davis II (1991) describes several alteration types in the Comstock District, mostly based on Whitebread (1976), Hudson (1986) and Hutsinpiller (1988). These include kaolinitic, illitic, sericitic and minor alunitic alteration. Propylitic alteration is pervasive in the region and show little association with structures. A link age between the alteration haloes and ore is not well established, but all the gold and silver deposits in the Virginia City Quadrangle are related to faults (Whitebread, 1976) and the main faults in the region are very closely related with the hydrothermally altered areas. Hutsinpiller (1988) demonstrated a intimate association between fault/ore, using TM-Landsat, aerial photographs and field data. Vikre (1989) proposed that the alteration types may have formed in response to intrusion events. He noted two agegroup clusters of quartz-alunite alteration and estimated that the ore deposition has occurred synchronous with the Kate Peak intrusion.

According to the epithermal zonation proposed by Hudson (1986) for the Virginia City district, gold and silver 
ore are thought to have been deposited at 700 to 850 meters below the surface, within the sericite-quartz facies. Mineral assemblages identified by this author are:

-Propylitic: chlorite, epidote, calcite, quartz, pyrite, illite/sericite

-Illitic: illite, quartz, pyrite, montmorillonite

-Kaolinitic: kaolinite, quartz, pyrite

-Advanced Argillic: pyrophyllite, quartz, diaspore, kaolinite, pyrite

-Alunitic: quartz, alunite, pyrite

-Sericitic: sericite, quartz, pyrite

-Silicic: quartz, calcite

Minerals shown above in bold letters have diagnostic absorption features within the 400 to $2,500 \mathrm{~nm}$ region of the spectrum used by RSp.

\section{ALTERATION MAP OF THE COMSTOCK LODE DISTRICT USING LANDSAT TM}

Remote sensing has been widely used to map hydrothermal alteration minerals in different regions of the world, based on spectral characteristics of some of the above mentioned minerals. However, current satellite multispectral sensors, such as Landsat TM, do not have enough spectral resolution to distinguish between these minerals. They only can be used to locate probable areas of occurrence of hydrothermal alteration. Landsat TM data is able to differentiate between "iron" $\left(\mathrm{Fe}^{3+}\right)$ alteration, (e.g. sulfides in altered rocks) and "clay/carbonate" (kaolinite, illite/ sericite, montmorillonite, alunite, calcite).

Spectral features due to these minerals may be not clearly shown in remotely sensed images, despite their peculiar or specific spectral behavior in laboratory. In images, they commonly represent only a fraction of the information content of each pixel, being therefore obscured by more prominent spec- tral features, such as vegetation in a non-arid environment. Thus spectral features due to minerals may form very subtle patterns in remotely sensed imagery and have therefore to be enhanced for interpretation. One of the most efficient methods used for enhancing the spectral information due to alteration minerals is principal component analysis (PCA). PCA forms the basis of some techniques specifically designed to extract information related to iron and clay/carbonate alteration from Landsat TM or other multispectral data. One of these techniques, known as feature-orientated principal component selection FPCS - (Crósta \& Moore, 1989 and Loughlin, 1991) has been widely used for mapping hydrothermally altered rocks (Spatz, 1996; Sabine, 1997). The use of PCA as pseudo-ratios also produces good results, as described in the literature (e.g. Souza Filho, in this issue).

Figure 3 shows the result of alteration mapping of the Comstock District using Landsat TM data processed through the above mentioned, FPCS technique (from research by R.L. Bedell Jr. and G. Heston, personal comunication) and here presented far reference of the spectral behavior of hydrothermally altered rocks at the studied region. The study area in this image lies between the VC (Virginia City, at the center of the image), and GH (Gold Hill, at the lower center) respectively (Fig. 1). The surface expression of iron oxides shows up in this image as red and yellow shades. They occur mostly associated to mine tailings containing oxidized pyrite near Virginia City, Gold Hill, Silver City (SC), Dayton (D), Six Mile Canyon (6C) and Geiger Grade (GG). Pixels dominated by clay minerals and carbonates appear in blue, while pixels containing both groups (iron and clay/carbonate) appear in white. 


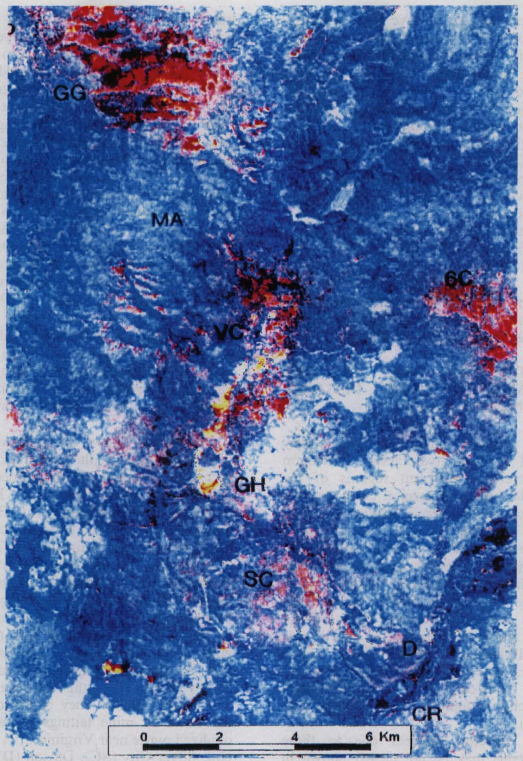

Figure 3 - Color composite of principal component images obtained by the feature-orientated principal component selection technique for the Comstock District, Nevada, USA. The study area is marked. Initials marked on the image indicate the approximate locations for Virginia City (VC), Gold Hill (GH), Geiger Grade (GG), Six Mile Canyon (6C) and Silver City (SC), representing main occurrences of hydrothermal alteration. The study area is imediately south VC. 


\section{MATERIALS AND METHODOLO- GY}

\section{Field Work}

Field work comprised two steps. Firstly, a broad traverse along the road from Reno to Virginia City was carried out and some hydrothermally altered rocks assessed. Secondly, we investigated a small area between Virginia
City and Gold Hill in detail. Ten samples where collected within this area, comprising different types of altered material. This location is shown in Figure 3 by areas of red, yellow and white shades. Natural colors of these samples ranged from pure white to yellowish-red and red (these later with greater amounts of iron oxide), as shown in Table 1 .

Table 1 - Description of samples and minerals identified by reflectance spectrometry and by X-ray diffraction. Quartz was also identified by XRD in all samples.

\begin{tabular}{|c|c|c|c|}
\hline Sample & Description & $\begin{array}{c}\text { Minerals identified by } \\
\text { Reflectance Spectrometry } \\
\text { (RSp) }\end{array}$ & $\begin{array}{c}\text { Minerals Identified By } \\
\text { X-Ray Diffraction } \\
\text { (XRD) }\end{array}$ \\
\hline T01 & $\begin{array}{l}\text { oxidized zone; } \\
\text { reddish colors }\end{array}$ & illite, alunite, hematite & $\begin{array}{c}\text { alunite, magnetite, } \\
\text { pyrophyllite }\end{array}$ \\
\hline T02 & $\begin{array}{l}\text { clay zone, oxidized; } \\
\text { yellow-greenish colors }\end{array}$ & $\begin{array}{l}\text { goethite, illite, } \\
\text { montmorillonite }\end{array}$ & $\begin{array}{l}\text { goethite, sepiolite, } \\
\text { chlorite (clinochlore) }\end{array}$ \\
\hline $\mathrm{T} 03$ & $\begin{array}{l}\text { clay zone, oxidized; } \\
\text { yellow-greenish colors }\end{array}$ & $\begin{array}{l}\text { goethite, montmorillonite, } \\
\text { chlorite (?) }\end{array}$ & $\begin{array}{l}\text { chlorite (clinochlore), } \\
\text { sepiolite }\end{array}$ \\
\hline T04 & $\begin{array}{l}\text { clay zone, oxidized; } \\
\text { pale yellow color }\end{array}$ & $\begin{array}{l}\text { hematite, montmorillonite, } \\
\text { sepiolite }\end{array}$ & $\begin{array}{c}\text { goethite, hematite, } \\
\text { sepiolite }\end{array}$ \\
\hline T05 & $\begin{array}{c}\text { clay zone; } \\
\text { whitish colors }\end{array}$ & alunite, sepiolite; goethite & pyrophyllite, microcline \\
\hline T06 & $\begin{array}{l}\text { clay zone; } \\
\text { white color }\end{array}$ & kaolinite, nacrite, illite (?) & kaolinite, microcline \\
\hline T07 & $\begin{array}{l}\text { clay zone; } \\
\text { white color }\end{array}$ & $\begin{array}{c}\text { kaolinite, nacrite, rectorite } \\
\text { (?) }\end{array}$ & kaolinite, nacrite \\
\hline T08 & $\begin{array}{l}\text { clay zone; } \\
\text { white color }\end{array}$ & montmorillonite & kaolinite, montmorillonite \\
\hline T09 & $\begin{array}{c}\text { clay zone; } \\
\text { whitish colors }\end{array}$ & $\begin{array}{l}\text { montmorillonite, rectorite, } \\
\text { goethite }\end{array}$ & kaolinite, rectorite \\
\hline T10 & $\begin{array}{l}\text { clay zone, slightly } \\
\text { oxidized; } \\
\text { pale yellow color }\end{array}$ & rectorite, hematite & illite, kaolinite \\
\hline
\end{tabular}

\section{Spectral Analysis}

Spectral analysis of the ten samples was carried out at the Desert Research Institute, Reno, Nevada, using a Beckman UV-5240 laboratory spectrometer, equipped with an integrating sphere model 198851. This integrating sphere is designed to detect total or dif- fuse reflectance using monochromatic radiation generated by an internal energy source in the 250 to $2,500 \mathrm{~nm}$ range. It has a photomultiplier for making measurements in the ultraviolet and visible regions of the electromagnetic spectrum and a lead sulphide cell for the near infrared region. It presents a good 
performance for samples with high scattering. The only sample preparation required is fragmentation to hand sample dimensions. The Beckman UV 5240 provides direct readings and outputs the results to a computer file. It has two operational modes, one covering the ultraviolet, visible and near infrared (between 190 and $800 \mathrm{~nm}$ ), with a resolution of $0.2 \mathrm{~nm}$, and the other in the infrared (between 800 and $3,000 \mathrm{~nm}$ ), with a resolution of $1.2 \mathrm{~nm}$. Precision is quoted as 0.5 and $2.5 \mathrm{~nm}$ for each region, respectively.

The operation of the instrument is preceded by calibration. This is achieved by reading two standards, one "white", made of barium suphate, and the other "black", made of a metal piece painted in opaque black color. Readings are done through scanning of the sample along the two wavelengths ranges; each of these ranges produce an individual spectral plot. There are eight different speeds to select, with slower scanning speeds allowing better signal-to-noise ratios. Samples are placed within the integrating sphere compartment, against the reading window located in the lower part of the sphere. The horizontal position of the window allows unconsolidated materials, such as soils or weathered rocks, to be easily analyzed. Reading is not continuous, since filters have to be changed along the wavelength ranges. There are four filters in the 290 to $800 \mathrm{~nm}$ range and five in the 800 to $2,500 \mathrm{~nm}$ range. Each of these changes produces some noise in the final results, which can be easily identified since filter changes occur at fixed wavelengths. The equipment is driven by a PC-type microcomputer and the analysis takes a few minutes for each sample.

After the scanning, the results are output to the PC. A software applies a smoothing filter to the curve to remove minor noise. The results finally output to an ASCII file, formatted in 2 columns and 2,089 lines, each column containing a wavelength position and its respective reflectance reading. A plotting software is used to produce the final spectral curve for analysis (e.g. MS-Excel).

Modern portable spectrometers, such as the FieldSpec and GER's 3700, manufactured by Analytical Spectral Devices (ASD) and Geophysical \& Environmental Research Corp., respectively, can perform the same type of analysis described above for the Beckman, but in a matter of seconds. Such spectrometers also perform several readings for each sample, maximizing the signal-to-noise ratio.

\section{Interpretation of the results}

Interpretation of the spectral plots was done visually, based on the criteria proposed by Hauff (1995). Reference spectra used as standards for comparison were extracted from the USGS Digital Spectral Library (Clark et al., 1993). Hauff's criteria take into account the position, shape and type of the main diagnostic absorption features for alteration minerals at two wavelength ranges: from 400 to $1,000 \mathrm{~nm}$ and from 2,000 to $2,500 \mathrm{~nm}$. By considering these parameters and comparing them with the standards from the spectral library it is possible to identify the minerals responsible for each absorption. The USGS library contains spectral plots for nearly 500 materials (mostly minerals) in the $400-2,500 \mathrm{~nm}$ spectral range; it represents the best spectral reference library currently available.

There are software packages that carry out this interpretation automatically, but they were not available for this work. These software are used by modern field spectrometers, such as ASD's FieldSpec or GER's 3700, thus allowing minerals to be identified on the spot, in real time. These softwares run on the same palmtop or laptop computer 
that is used to operate the spectrometers.

The first step in interpreting the spectral plots is to verify the occurrence of intense absorption features and the exact wavelengths position at which they occur. The shape of the feature is then considered, so if it is a either single or a double feature (known as "doublet"). Next, the secondary (less intense) features are analyzed in the same way. By comparing the results with spectral plots of reference minerals from the library the interpreter may get to some minerals or groups of minerals with similar features, being then able to select those more similar to the plot being analyzed.

Absorption features in the 400 to $1,000 \mathrm{~nm}$ range are usually indicative of $\mathrm{Fe}^{3+}$ oxides, hydroxides and sulphates (e.g. jarosite). These features are caused by phenomena that occur at electronic level in the ferric ion. There are two different types of phenomena related to minerals containing $\mathrm{Fe}^{3+}$ that produce absorption features at different wavelength positions within this range. One is charge transfer, responsible for a generalized absorption in the ultraviolet, which decreases towards the visible and near infrared wavelengths. A second type, the crystal field effect, produces absorption features at intervals between $450-650 \mathrm{~nm}$ and $850-950 \mathrm{~nm}$ depending on the specific mineral; these are usually more diagnostic than the charge transfer feature. Goethite, for example, shows a smaller feature at $650 \mathrm{~nm}$ and a more intense one at around $900 \mathrm{~nm}$, whereas hematite usually does not show the feature at $650 \mathrm{~nm}$ and has a intense absorption around $850 \mathrm{~nm}$. Jarosite also shows an absorption around $900 \mathrm{~nm}$, but can be differentiated from goethite for showing a secondary absorption between 400 and $500 \mathrm{~nm}$ (Hunt \& Ashley, 1979). In the 1,400 to $2,500 \mathrm{~nm}$ range another phenomenon is responsible for energy absorption. This vibra- tional phenomenon is due to the presence of the hydroxyl $(\mathrm{O}-\mathrm{H})$ molecule in the minerals, common in many hydrothermal alteration minerals. Water is also responsible for important absorption features at 1,400 and $1,900 \mathrm{~nm}$, that may obscure hydroxyl features.

Figures $4 \mathrm{a}$ to $4 \mathrm{~d}$ present spectral plots of some minerals extracted from the USGS library. These are some of the minerals used as reference for interpreting the mineralogy of the Comstock samples. Figures $5 \mathrm{a}$ to $5 \mathrm{j}$ show the spectral plots for the Comstock samples analyzed using the Beckman. Some features that can be seen at 970-1,015, $1,455-1,510$ and $2,265-2,310$ represent noise, caused by filter change during the Beckman operation. These could not be removed by smooth filtering and should be disregarded.

\section{X-Ray Diffraction}

The samples, ground to 100 mesh, were analyzed by XRD at the Instituto de Geociências/USP facilities, producing results which were difficult to interpret due to strong secondary quartz peaks. A sample preparation was then carried out at the Technological Characterization Laboratory (Escola Politécnica/USP), consisting of a partial extraction of the clay fraction: a sample aliquot was mixed in warm water and, after 15 minutes, the particles in suspension, dominantly sheetsilicates, were sampled for XRD analysis. Interpretation of XRD results was done through a interactive software (Difrat AT software).

\section{DISCUSSION OF RESULTS}

Table 1 presents the minerals identified by reflectance spectrometry and by X-ray diffraction and a brief description of the Comstock samples.

Table 1 shows that the results obtained for both methods are not exactly 

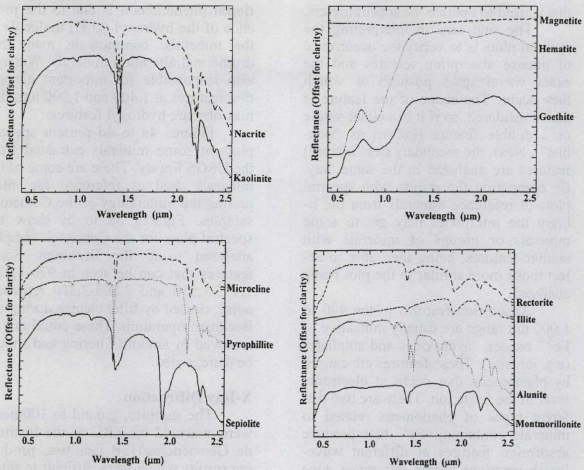

Figure 4 - Spectral plots of some selected minerals (modified from Clark et al., 1993). Wavelength in microns.

equal. Some differences in the minerals identified relate to minerals of a same group, which are difficult to distinguish (rectorite, for example, is a mixed clay, which contains alternating layers of illite and montmorillonite). There are cases, however, in which both methods produced very different results. This is probably due to the subjective nature of visual interpretation for the RSp results and to the approximation made by the semi-automatic method used for interpreting XRD results. This method also showed the presence of magnetite in sample T01, which could not be identified by RSp since this mineral does not have any significant spectral feature (Fig. 4a). On the other hand, hematite was clearly shown in sample T01 by
$\mathrm{RSp}$ and was not detected by XRD. A similar case is shown by sample T03, in which goethite was indicated by RSp and not by XRD, despite the yellowish shade of the sample, which suggests at least the presence of iron oxides or hydroxides, not indicated by XRD. The presence of some quartz, that remained even after sample preparation, caused the appearance of secondary peaks in the XRD results, which may have obscured some minor features due to other minerals related to alteration.

\section{CONCLUDING REMARKS}

Analysis of hydrothermally altered rocks of the Comstock Lode area by reflectance spectrometry and X-ray dif- 


\section{Sample T01}

1- Hernatite; 2-Alunite; 3 - Ilite

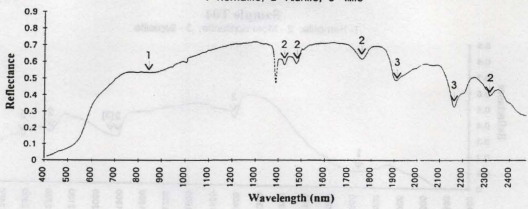

Sample T02

1- Goethite; 2-Montmorilionife; 3- Ilite

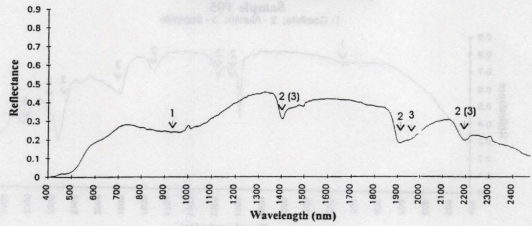

Sample T03

1-Goethite; 2 - Montmorillonite: 3-Chlorite [?]

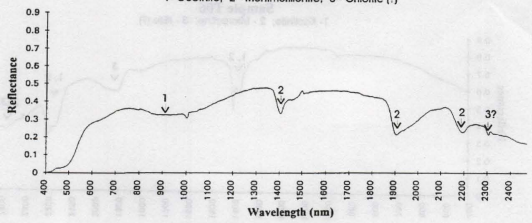

Figure 5 - Spectral plots for the Comstock samples analyzed by the Beckman spectrometer with the interpretation. Wavelength in nanometers. 

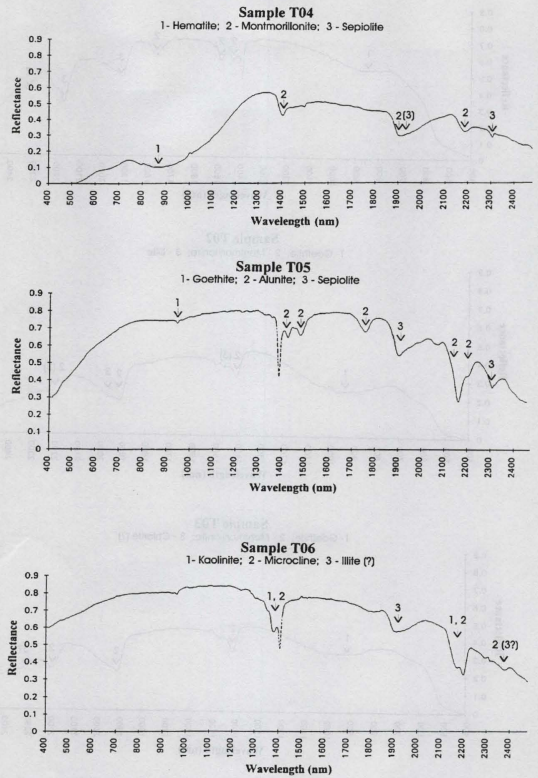

Figure 5 - (continuation). 


\section{Sample T07}

1-Kaolinite; 2 - Nacrite; 3-Rectorite (?)

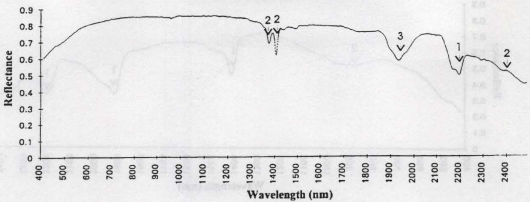

\section{Sample T08}

1-Montmorilonite

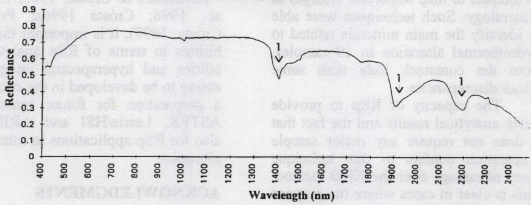

\section{Sample T09}

1-Goethilte: 2 - Montmorlilonite; 3 - Rectorite

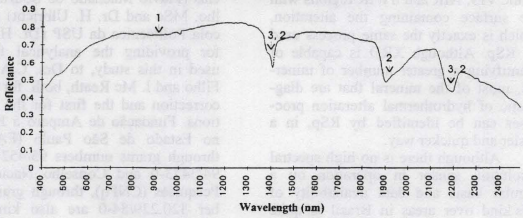

Figure 5 - (continuation). 


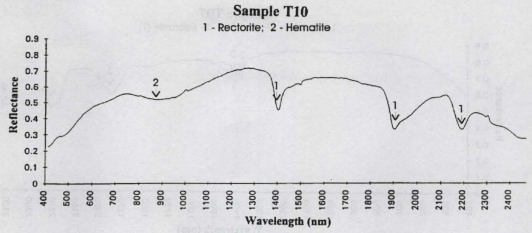

Figure 5 - (conclusion).

fraction show the capabilities of both techniques to map important changes in mineralogy. Such techniques were able to identify the main minerals related to hydrothermal alteration in 10 samples, from the comstock lode with some minor discrepancies.

The capacity of RSp to provide quick analytical results and the fact that it does not require any major sample preparation confers to this technique some advantage over the XRD method. This is clear in cases where the purpose of the analysis is related to remote sensing data. Detection of minerals in remote sensing is achieved by the interaction of the electromagnetic radiation in the VIS, NIR and SWIR regions with the surface containing the alteration, which is exactly the same process used by RSp. Although XRD is capable of identifying a greater number of minerals, most of the mineral that are diagnostic of hydrothermal alteration processes can be identified by RSp, in a easier and quicker way.

Although there is no high spectral resolution sensor in operation on a regular basis and data availability of this kind over areas in Brazil is quite limited (mostly restricted to proprietary Geoscan data over regions in Minas Gerais and Bahia states and a few
AVIRIS flight lines over Central Brazil - Hernandes \& Crósta, 1995; Crósta et al., 1996; Crósta 1996a; Prado \& Crósta, 1997), it is important that capabilities in terms of RSp analytical facilities and hyperspectral image processing to be developed in the country, as a preparation for future sensors like ASTER, Lewis/HSI and ARIES and also for RSp applications in mineral exploration.

\section{ACKNOWLEDGMENTS}

The authors wish to thank the Desert Research Institute, University of Nevada System, Instituto de Geociências (Flávio Machado de Souza Carvalho, MSc and Dr. H. Ulbricht) and Escola Politécnica da USP (Dr. H. Kahn) for providing the analytical facilities used in this study, to Drs. C.A. Souza Filho and I. Mc Reath, both for the text correction and the first for the suggestions. Fundação de Amparo à Pesquisa no Estado de São Paulo (FAPESP), through grants numbers $95 / 4529-6$ and 94/3473-0 and Conselho Nacional de Pesquisas $(\mathrm{CNPq})$, through grant number $320.229 / 84-0$ are also kindly acknowledged for providing financial support and travel grants. The Landsat TM image presented in Figure 3 was 
processed and kindly provided for this paper by R. L. Bedell Jr. and G. Heston, from Homestake Mining Company, Sparks, USA.

\section{REFERENCES}

BONHAM, A.F. (1969) Geology and mineral deposits of Washoe and Storey Counties, Nevada. Nevada Bureau of Mines and Geology, Bulletin, v. 70, p.1-140.

CARRERE, V. (1989) Mapping alteration in the Goldfield Mining District, Nevada, with the airborne VNIR/ SWIR imaging spectrometer, AVIRIS. In: THEMATIC CONFERENCE ON REMOTE SENSING FOR EXPLORATION GEOLOGY, 7., Calgary, Canada, 1989. Proceedings. Calgary, ERIM, v.1, p.365378

CLARK, R.N.; SWAYZE, A.J.; GALLAGHER, A.J.; KING, T.V.V.; CALVIN, W.M. (1993) The USGS digital spectral library version $1: 0.2$ to $3.0 \mathrm{~mm}$. USGS, Denver, CO. Open File Report, p.93-592.

CRÓSTA, A.P. (1996a) Sensoriamento remoto hiperespectral: uma nova ferramenta de prospecção mineral. In: CONGRESSO BRASILEIRO DE GEOLOGIA, 39., Salvador, 1996. Boletim de Resumos Expandidos. Salvador, SBG. v.3, p.3-6.

CRÓSTA, A.P. (1996b) Século XXI em alta resolução. Fator GIS, v.4, n. 15, p. 14-17.

CRÓSTA, A.P.; MOORE, J.McM. (1989) Enhancement of landsat thematic mapper imagery for residual soil mapping in SW Minas Gerais state, Brazil: a prospecting case history in greenstone belt terrain. In: THEMATIC CONFERENCE ON REMOTE SENSING FOR EXPLORATION GEOLOGY, 7., Calgary, Canada, 1989. Proceedings. Calgary, ERIM, v.2, p.1173-1187
CRÓSTA, A.P.; SABINE, C.; TARANIK, J.V. (1996) High-spectral resolution remote sensing for mineral mapping in the Bodie and Paramount mining districts, California. International Archives of Photogrammetry and Remote Sensing, v.31, n.7, p.161-166.

DAVIS II, W.P. (1991) Production of alteration maps using airborne high-resolution multi-specral imagery: Virginia City, Nevada, 63p. (MSc. Thesis) - Stanford University.

GOETZ, A.F.H. (1989) Spectral remote sensing in geology. In: ASRAR, G. (ed.). Theory and Applications of optical remote sensing. New York, John Wiley \& Sons. 770 p.

HAUFF, P.L. (1995) Introduction to applied reflectance spectroscopy Section II. Spectral International Inc., March 1995. 130p.

HERNANDES, G.L.S.; CRÓSTA, A.P. (1995) Espectrometria de reflexão aplicada à exploração de depósitos auríferos por sensoriamento remoto na região de Riacho dos Machados, MG, Brasil. In: SIMPOSIO LATINOAMERICANO DE PERCEPCIÓN REMOTA. SELPER, 7., Puerto Vallarta, México, 1995. Proceedings. p.445-456.

HESS, R.; FAUST, G.; TRACY, M. (1987) Mining history and places names of the Comstock Area - a field trip guidebook. Nevada, Bureau of Mines \& Geology. Report 87-6, 35p.

HUDSON, D.M. (1986) The Comstock District. Field Trip Guidebook. Geological Society of Nevada, v.4, p. 1-13.

HUNT, G.R.; ASHLEY, R.P. (1979) Spectra of altered rocks in the visible and near infrared. Economic Geology, v. 74, p.1613-1629.

HUTSINPILLER, A. (1988) Discrimination of hydrothermal alteration mineral assemblages at Virginia City, 
Nevada, using airborne imaging spectrometer. Remote Sensing of Environment, v.24, p.53-66.

LEE, K.; RAINES, G.L. (1984) Reflectance spectra of some alteration minerals - a chart compiled from published data. U.S.G.S. Open File Report, n.84-96. p.1-6.

LOUGHLIN, W.P. (1991) Principal component analysis for alteration mapping. Photogrammetric Engineering \& Remote Sensing, v.57, n.9, p.1163-1169.

PRADO, I. D. M.; CRÓSTA, A. P. (1997) Evaluating Geoscan AMSS Mk-II for gold exploration in the Fazenda Maria Preta District, Rio Itapicuru Greenstone Belt, Bahia State, Brazil. (in this issue).

ROCKWELL, B.W. (1991) Evaluation of GERIS airborne spectrometer data analysis for disseminated gold exploration: a case study from the Getchell trend, Nevada. In: THEMATIC CONFERENCE ON REMOTE SENSING FOR EXPLORATION GEOLOGY, 8., Denver, Nevada, 1991. Proceedings. Denver, ERIM. p. 837-850.

ROWAN, L.C. (1983) Near-infrared iron absortion bands: applications to geologic mapping and mineral exploration. In: WATSON; REGAN, (eds.). Remote sensing society of explorations in geophisicists, Reprint Series, v.3, p. 250-268.

SABINE, C. (1997) Remote sensing for mineral exploration. In: Manual of remote sensing. 3.ed. ASPRS (in press).

SPATZ, D. (1996) Remote sensing characteristics of precious metals systems. In: THEMATIC CONFERENCE ON REMOTE SENSING FOR EXPLORATION GEOLOGY, 11., Las Vegas, Nevada, 1996. Proceedings. Las Vegas, ERIM. v.1, p. 1-22.

TARANIK, D. L.; KRUSE, F. A. GOETZ, A.F.H.; ATKINSON, W.W. (1991) Remote sensing of ferric iron minerals as guides for golg exploration. In: THEMATIC CONFERENCE ON REMOTE SENSING FOR EXPLORATION GEOLOGY, 8., Denver, Colorado, 1991. Proceedings. Denver, ERIM. p.197-228.

TARANIK, J.V.; CRÓSTA, A.P. (1996) Remote sensing for geology and mineral resources: an assessment of tools for geoscientists in the near future. International Archives of Photogrammetry and Remote Sensing, v.31, n.B7, p.689-698.

VIKRE, P.G. (1989) Fluid mineral-relations in the Comstocke Lode. Economic Geology, v.84, p.1574-1613.

T.I.Ribeiro de Almeida - Instituto de Geociências, Universidade de São Paulo, Caixa Postal 11.348, CEP 05422-970, São Paulo, SP, Brasil. 